\title{
Neuroprotective effects of hydrogen sulfide on sodium azide-induced oxidative stress in PC12 cells
}

\author{
CHENG GAO $^{1,2^{*}}$, PAN CHANG $^{3 *}$, LIJUN YANG $^{2 *}$, YI WANG $^{2}$, SHAOHUA ZHU $^{2}$, \\ HAIYAN SHAN ${ }^{4,5}$, MINGYANG ZHANG ${ }^{1,2,5}$ and LUYANG TAO ${ }^{2}$
}

\begin{abstract}
${ }^{1}$ Key Laboratory of Evidence Science, China University of Political Science and Law, Ministry of Education, Beijing 100088; ${ }^{2}$ Institute of Forensic Sciences, Soochow University, Suzhou, Jiangsu 215123; ${ }^{3}$ Central Laboratory, The Second Affiliated Hospital of Xi'an Medical College, Xi'an, Shaanxi 710038; ${ }^{4}$ Department of Obstetrics and Gynecology, North District of Suzhou Municipal Hospital, Suzhou, Jiangsu 215000, P.R. China; ${ }^{5}$ Department of Cell Biology and Neuroscience, Rutgers, The State University of New Jersey, Piscataway, NJ 08854, USA
\end{abstract}

Received April 16, 2017; Accepted October 19, 2017

DOI: $10.3892 / \mathrm{ijmm} .2017 .3227$

\begin{abstract}
Alzheimer's disease (AD) is the most common neurodegenerative disorder, responsible for $>50 \%$ of all dementia cases. Sodium azide $\left(\mathrm{NaN}_{3}\right)$ inhibits cytochrome oxidase by irreversibly binding to the heme cofactor and selectively reducing the complex IV activity, which is present in post-mortem AD brains. Previous data demonstrated that hydrogen sulfide $\left(\mathrm{H}_{2} \mathrm{~S}\right)$, the third endogenous gaseous mediator, exerted protective effects against neuronal damage. Therefore, it was hypothesized that $\mathrm{H}_{2} \mathrm{~S}$ may be able to scavenge excess reactive oxygen species (ROS), thereby protecting against oxidative stress and cell death. In the present study, it was observed that cell viability decreased in a concentration-dependent manner $12 \mathrm{~h}$ after $\mathrm{NaN}_{3}$ treatment $(20,30$ and $50 \mathrm{mmol} / \mathrm{l})$. A decrease in cell viability (to $51 \pm 3 \%$ ) was observed $12 \mathrm{~h}$ after treatment with $30 \mathrm{mM} \mathrm{NaN}_{3}$. $\mathrm{NaN}_{3}$ treatment also led to decreased mitochondrial membrane potential, increased lipid peroxidation (excessive production of malondialdehyde), and increased the protein expression levels of caspase-3. Pretreatment with $\mathrm{H}_{2} \mathrm{~S}(200 \mu \mathrm{mol} / \mathrm{l})$ attenuated $\mathrm{NaN}_{3}$-mediated apoptosis, and the anti-apoptotic action of $\mathrm{H}_{2} \mathrm{~S}$ was partially dependent on suppressing the production
\end{abstract}

Correspondence to: Dr Mingyang Zhang, Institute of Forensic Sciences, Soochow University, 178 East Ganjiang Road, Suzhou, Jiangsu 215123, P.R. China

E-mail: mingyangzhang@suda.edu.cn

Dr Haiyan Shan, Department of Obstetrics and Gynecology, North District of Suzhou Municipal Hospital, 242 South Guangji Road, Suzhou, Jiangsu 215000, P.R. China

E-mail: ghostqth@163.com

${ }^{*}$ Contributed equally

Key words: hydrogen sulfide, sodium azide, oxidative stress, PC12 cells of ROS. The findings of the present study suggested that $\mathrm{H}_{2} \mathrm{~S}$ exerted a neuroprotective effect against $\mathrm{NaN}_{3}$-induced neurotoxicity through mechanisms related to anti-oxidation and anti-apoptosis. Therefore, the findings of the present study suggest there may be a promising future for $\mathrm{H}_{2} \mathrm{~S}$-based preventions and therapies for neuronal damage following exposure to $\mathrm{NaN}_{3}$.

\section{Introduction}

Alzheimer's disease (AD) is a neurodegenerative disorder, accounting for $50-70 \%$ of all dementia cases and affecting $>12$ million individuals worldwide. AD is an age-related neurodegenerative illness characterized by a progressive decline in cognitive functions, and histopathologically by the presence of neuritic plaques containing amyloid- $\beta$ (A $\beta)$ peptide and neurofibrillary tangles, mostly constisting of hyperphosphorylated Tau protein (1). AD exists in familial (early- and late-onset) forms, as well as a sporadic form, which is very common, accounting for $\sim 90 \%$ of all cases. AD has a complex multietiological origin; however, its exact genetic and environmental causative factors are unknown. Increasing evidence indicates that different processes contribute to neurodegeneration, including mitochondrial dysfunction, oxidative stress and impairment of the autophagic/lysosomal/endosomal system $(2,3)$. Numerous studies have demonstrated that oxidative stress is one of the initiating events and one of the molecular changes underlying the pathogenesis of $\mathrm{AD}(4,5)$.

Oxidative stress may result from suppression of mitochondrial function. Cytochrome oxidase (COX) is a mitochondrial enzyme that plays an important role in aerobic energy metabolism and mitochondrial function. Mitochondrial abnormalities, particularly of COX, are found in the brains of subjects with $\mathrm{AD}$ (6). The principal toxic action of sodium azide $\left(\mathrm{NaN}_{3}\right)$ is inhibiting the function of $\mathrm{COX}$ in the mitochondrial electron transport chain (7). The model of brain mitochondrial COX inhibition by $\mathrm{NaN}_{3}$ was described in rats in an attempt to mimic the morphological and behavioral pathology of AD (8). The involvement of mitochondrial dysfunction and the consequent overproduction of reactive oxygen species (ROS) is 
increasingly recognized and widely accepted as an etiopathological factor of AD. The tissue-specific inhibition of COX by $\mathrm{NaN}_{3}$ may serve as a useful tool for the evaluation of $\mathrm{AD}$ in vivo and in vitro.

Hydrogen sulfide $\left(\mathrm{H}_{2} \mathrm{~S}\right)$, is considered as the third most abundant endogenous signaling gasotransmitter following nitric oxide (NO) and carbon monoxide, which affects physiological and pathophysiological processes in a wide range of biological systems (9). $\mathrm{H}_{2} \mathrm{~S}$ is produced endogenously in mammals, including humans. In particular, cystathionine- $\beta$-synthase (CBS) in the central nervous system (CNS) and cystathionine- $\gamma$-lyase in the cardiovascular system are the key enzymes that are mainly responsible for the endogenous generation of $\mathrm{H}_{2} \mathrm{~S}$ (10). 3-Mercaptopyruvate sulfurtransferase (3- MST) is also known to be a significant producer of endogenous $\mathrm{H}_{2} \mathrm{~S}$ in the brain (11). Increasing evidence demonstrates that $\mathrm{H}_{2} \mathrm{~S}$ is associated with AD pathogenesis (12). The dysfunction of CBS in the transsulfuration pathway may lead to a decrease in $\mathrm{H}_{2} \mathrm{~S}$ production in $\mathrm{AD}$ (13). Interestingly, the levels of $\mathrm{H}_{2} \mathrm{~S}$ are severely decreased in $\mathrm{AD}$ patients; moreover, plasma $\mathrm{H}_{2} \mathrm{~S}$ levels are negatively correlated with the severity of the disease in AD patients (14). Moreover, our previous research demonstrated downregulation of the expression and activity of CBS and 3-MST in neuron-like rat pheochromocytoma (PC12) cells induced by $\mathrm{NaN}_{3}$ (data not shown). However, it is not known whether $\mathrm{H}_{2} \mathrm{~S}$ has any therapeutic benefits in AD. Therefore, the present study was undertaken to assess the beneficial effects of sodium hydrosulfide (NaHS), which is an exogenous $\mathrm{H}_{2} \mathrm{~S}$ donor, on the underlying cellular and molecular mechanisms in neuronal cells treated with $\mathrm{NaN}_{3}$.

The characteristics of neuronal damage induced by $\mathrm{NaN}_{3}$ treatment were first investigated. The neuroprotective activity of $\mathrm{H}_{2} \mathrm{~S}$ and its effect on oxidative stress were also investigated in PC12 cells with neuronal damage induced by $\mathrm{NaN}_{3}$. To the best of our knowledge, this is the first study to demonstrate that $\mathrm{H}_{2} \mathrm{~S}$ can suppress $\mathrm{NaN}_{3}$-induced oxidative stress and apoptosis in PC12 cells. This study was conducted to gain better insight into the physiological functions of $\mathrm{H}_{2} \mathrm{~S}$ under normal and injury conditions, and its association with the cellular and molecular mechanisms underlying nervous system disease.

\section{Materials and methods}

Cell culture. Rat pheochromocytoma PC12 cells were obtained from the Shanghai Institute of Cell Biology, Chinese Academy of Sciences (Shanghai, China). PC12 cells were grown on polystyrene tissue culture dishes in DMEM containing $10 \%$ horse serum and 5\% fetal bovine serum (FBS; Sijiqing Biological Engineering Materials Co., Ltd., Hangzhou, China), supplemented with $2 \mathrm{mmol} / \mathrm{l}$ glutamine, $100 \mu \mathrm{g} / \mathrm{ml}$ streptomycin, and $100 \mathrm{U} / \mathrm{ml}$ penicillin (Gibco; Thermo Fisher Scientific, Inc., Waltham, MA, USA) at $37^{\circ} \mathrm{C}$ with $95 \%$ air, $5 \% \mathrm{CO}_{2}$. Prior to differentiation, the medium was exchanged twice a week and the cultures were subcultured at a ratio of 1:4 once a week. For differentiation, the cells were washed and incubated in a fresh medium containing nerve growth factor (NGF; final concentration, $50 \mathrm{ng} / \mathrm{ml}$ ) for $48 \mathrm{~h}$ at $37^{\circ} \mathrm{C}$ in a cell incubator. The concentration of NGF was maintained throughout all experiments. All the experiments were performed on cells between passages 3-8.

Cell injury model. The injury model was constructed as follows: briefly, the DMEM was removed, PC12 cells were washed twice with glucose-free Earle's balanced salt solution (EBSS) at pH 7.5, and maintained in glucose-free DMEM without FBS. Subsequently, neurotoxic damage was induced by adding the indicated concentration of $\mathrm{NaN}_{3}$ to the cultured cells for different periods of time. The cells were preincubated with the indicated concentrations of $\mathrm{NaHS}$ (donor of $\mathrm{H}_{2} \mathrm{~S}$ ) for 30 min prior to $\mathrm{NaN}_{3}$ treatment and maintained throughout the entire experiment. NaHS was dissolved in saline and was freshly prepared immediately prior to use. The stock solutions were directly added into the bath solution to achieve the final concentration. Control cultures were maintained in DMEM for the same duration under normoxic conditions. The concentrations of all the reagents were maintained throughout the injury period.

Determination of cell viability. The viability of PC12 cells was determined using the Cell Counting Kit-8 (CCK-8) assay (Dojindo Molecular Technologies, Inc., Kumamoto, Japan), according to the manufacturer's instructions. PC12 cells were cultured in 96 -well plates at $37^{\circ} \mathrm{C}$ under an atmosphere of $5 \% \mathrm{CO}_{2}$ and $95 \%$ air. At the end of treatment, $\mathrm{CCK}-8$ reagent $(10 \mu \mathrm{l})$ was added to each well and the plates were then incubated at $37^{\circ} \mathrm{C}$ for 3 to $4 \mathrm{~h}$ in the incubator. Absorbance at a wavelength of $450 \mathrm{~nm}$ was measured with a microplate reader (BioTek Instruments, Inc., Winooski, VT, USA). The means optical density (OD) from 6 wells in the indicated groups were used to calculate the cell viability, which was expressed as a percentage of cell survival rate compared with the control. All the experiments were performed in triplicate and repeated three independent times.

Determination of mitochondrial membrane potential $(M M P)$. MMP was examined by staining PC12 cells with JC-1. Staining was performed using $2.5 \mathrm{mg} / \mathrm{ml} \mathrm{JC}-1$ at $37^{\circ} \mathrm{C}$ for $15 \mathrm{~min}$. After staining, cells were rinsed three times with phosphate-buffered saline (PBS). A confocal laser scanning microscope was used to measure MMP using the JC-1 assay kit (C2006; Beyotime Institute of Biotechnology, Haimen, China). Under the microscope, images of different color were obtained. Green fluorescence indicated cells with low MMP $(\Delta \psi \mathrm{m})$, revealing that JC-1 maintains (or reacquires) monomeric form, while red fluorescence indicated cells with high $\Delta \psi \mathrm{m}$. The relative proportions of red and green fluorescence were used to measure the extent of mitochondrial depolarization.

Intracellular ROS measurement. Production of intracellular ROS was determined using the fluorescent probe dichlorofluorescin diacetate (DCFH-DA), which can cross cell membranes and is subsequently hydrolyzed by intracellular esterase to non-fluorescent DCFH (Beyotime Institute of Biotechnology). Following treatment with $\mathrm{NaN}_{3}$ for $12 \mathrm{~h}$ in the presence or absence of $200 \mathrm{mM} \mathrm{H}_{2} \mathrm{~S}$, the culture medium was changed to fresh DMEM containing $10 \mu \mathrm{M}$ DCFH-DA for $30 \mathrm{~min}$ in an incubator at $37^{\circ} \mathrm{C}$ in the dark. After washing three times 
A

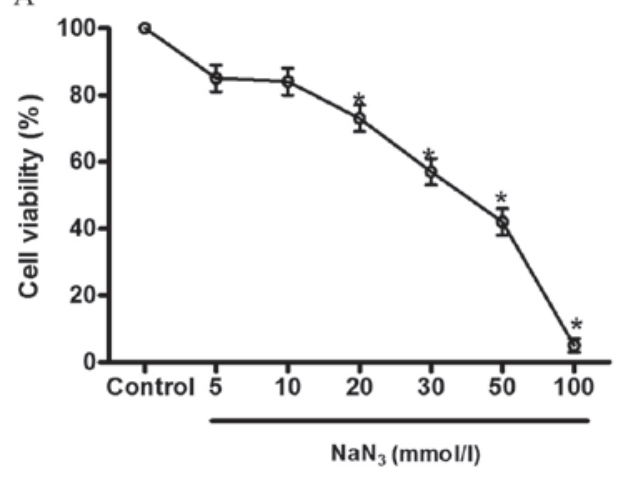

B

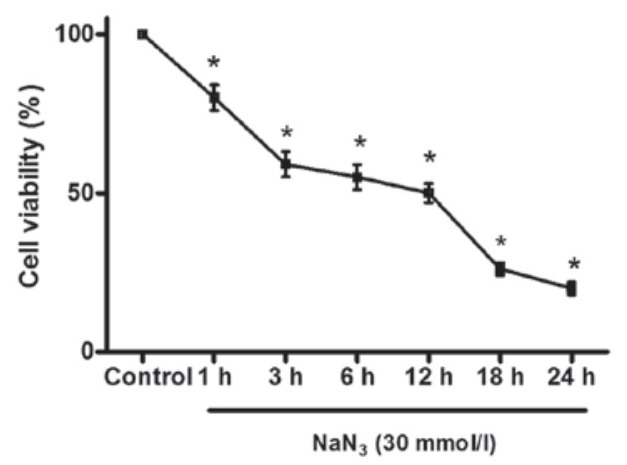

Figure 1. Concentration- and time-dependent effect of sodium azide $\left(\mathrm{NaN}_{3}\right)$ on cell viability in PC12 cells. (A) PC12 cells were treated with 5, 10, 20, 30, 50 and $100 \mathrm{mmol} / 1 \mathrm{NaN}_{3}$ for $12 \mathrm{~h}$, and cell viability was determined by the Cell Counting Kit-8 (CCK-8) assay. Exposure of PC12 cells to NaN $\mathrm{N}_{3}$ for $12 \mathrm{~h}$ induced a decrease in cell viability in a concentration-dependent manner. (B) PC12 cells were treated for 1,3,6,12, 18 and $24 \mathrm{~h}$ with $30 \mathrm{mmol}_{1} / \mathrm{NaN}_{3}$, and cell viability was determined by the CCK-8 assay. Exposure of PC12 cells to $30 \mathrm{mmol} / 1 \mathrm{NaN}_{3}$ induced a decrease in cell viability in a time-dependent manner. Columns represent means \pm standard error of the mean of viable cells $(n=6)$, and expressed as percentage of control values. " $\mathrm{P}<0.05$ vs. control group.

with PBS, the cells were observed under a fluorescence spectrophotometer with an excitation wavelength of $488 \mathrm{~nm}$ and an emission wavelength of $535 \mathrm{~nm}$.

Measurement of lipid peroxidation. Malondialdehyde (MDA), a terminal product of lipid peoxidation, was measured to estimate the extent of lipid peoxidation in PC12 cells. The cells were then homogenized in lysis buffer [1\% NP-40, $50 \mathrm{mmol} / 1$ Tris, pH 7.5, 5 mmol/1 EDTA, $1 \%$ sodium dodecyl sulphate (SDS), $1 \%$ sodium deoxycholate, $1 \%$ Triton X-100, 1 mmol/1 phenylmethanesulfonylfluoride, $10 \mu \mathrm{g} / \mathrm{ml}$ aprotinin, and $1 \mu \mathrm{g} /$ $\mathrm{ml}$ leupeptin] and clarified by centrifuging for $20 \mathrm{~min}$ in a microcentrifuge at $4^{\circ} \mathrm{C}$. MDA concentration in cell homogenates was determined with an MDA assay kit (S0131; Beyotime Institute of Biotechnology), using the thiobarbituric acid method. The assay was based on the ability of MDA to form a conjugate with thiobarbituric acid and create a red product, which has maximum absorbance at $532 \mathrm{~nm}$.

Western blot analysis. The cells were then homogenized in lysis buffer (1\% NP-40, $50 \mathrm{mmol} / 1$ Tris, PH 7.5, $5 \mathrm{mmol} / \mathrm{l}$ EDTA, $1 \%$ SDS, $1 \%$ sodium deoxycholate, $1 \%$ Triton X-100, $1 \mathrm{mmol} / 1$ phenylmethanesulfonylfluoride, $10 \mu \mathrm{g} / \mathrm{ml}$ aprotinin, and $1 \mu \mathrm{g} / \mathrm{ml}$ leupeptin) and clarified by centrifuging for $20 \mathrm{~min}$ in a microcentrifuge at $4^{\circ} \mathrm{C}$. Following determination of its protein concentration with the Bradford assay (Bio-Rad Laboratories, Inc., Hercules, CA, USA), the resulting supernatant (50 $\mu \mathrm{g}$ of protein) was subjected to SDS polyacrylamide gel electrophoresis. The separated proteins were transferred to a polyvinylidine difluoride membrane (Millipore, Billerica, MA, USA) by a transfer apparatus at $90 \mathrm{~V}$ for $1 \mathrm{~h}$. The membrane was then blocked with $5 \%$ non-fat milk and incubated with primary antibody against caspase- 3 (1:500, cat. no. BS1518) and Bcl-2 (1:500, cat. no. BZ00479) (both from Bioworld Technology, Inc., St. Louis Park, MN, USA) or GAPDH (1:1,000, cat. no. G8795; Sigma-Aldrich; Merck KGaA, St. Louis, MO, USA). After incubating with an anti-rabbit or anti-mouse horseradish peroxidase-conjugated secondary antibody, protein was visualized using an enhanced chemiluminescence system (ECL; cat. no. 32106; Pierce; Thermo Fisher Scientific, Inc., Bellefonte, PA, USA).
Immunofluorescence analysis. Immunofluorescence analysis was performed as follows: the PC12 cell in a 24 -well plate were fixed with $4 \%$ paraformaldehyde for $15 \mathrm{~min}$ at room temperature and washed with PBS three times, for $10 \mathrm{~min}$ each time. After the cells were prepared, they were blocked with 5\% donkey serum (Gibco; Thermo Fisher Scientific, Inc.) with $0.3 \%$ Triton $\mathrm{X}-100$ and $5 \%$ bovine serum albumin (BSA) for $2 \mathrm{~h}$ at room temperature and incubated with rabbit polyclonal primary anti-caspase-3 antibodies (1:50, cat. no. ab13847; Abcam, Cambridge, UK). Briefly, the cells were incubated with the primary antibodies overnight at $4^{\circ} \mathrm{C}$, followed by a mixture of fluorescein isothiocyanate-conjugated secondary antibodies for $2 \mathrm{~h}$ at room temperature, then washed with PBS three times, for $10 \mathrm{~min}$ each time. Finally, the samples were mounted with coverslips using antifade mounting medium (Beyotime Institute of Biotechnology) and observed under a fluorescence microscope (Eclipse Ti-S; Nikon, Tokyo, Japan). At least three random slides from each group were examined.

Statistical analysis. All statistical analyses were conducted with SPSS statistical software 16.0 (SPSS, Inc., Chicago, IL, USA). All the values are expressed as means \pm standard error of the mean. The statistical significance of differences between groups was determined by one-way analysis of variance followed by Tukey's post hoc multiple comparison tests or Student's t-test (two means comparison). $\mathrm{P}<0.05$ was considered to indicate statistically significant differences. Each experiment consisted of at least three replicates per condition.

\section{Results}

$\mathrm{NaN}_{3}$ is cytotoxic to PC12 cells. Cell cytoxicity was evaluated by the CCK- 8 assay following incubation of PC12 cells with increasing concentrations of $\mathrm{NaN}_{3}$ from 5 to $100 \mathrm{mmol} / \mathrm{l}$ at 1 , $3,6,12,18$ and $24 \mathrm{~h}$. As shown in Fig. 1A, at concentrations of 5-100 mmol/l, treatment of PC12 cells with $\mathrm{NaN}_{3}$ for $12 \mathrm{~h}$ led to a concentration-dependent reduction in cell viability. The results demonstrated that the general trend of cell survival rate decreased with increasing treatment time (Fig. 1B). 


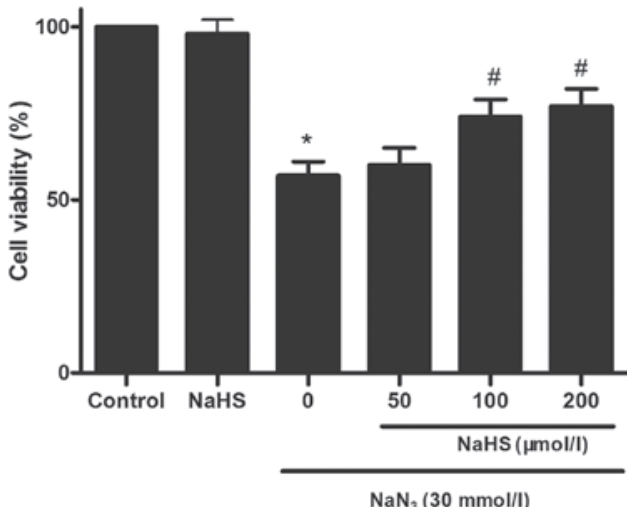

Figure 2. Protective effect of hydrogen sulfide $\left(\mathrm{H}_{2} \mathrm{~S}\right)$ against sodium azide $\left(\mathrm{NaN}_{3}\right)$-induced cytotoxicity in PC12 cells. PC12 cells were treated with $\mathrm{NaN}_{3}(30 \mathrm{mmol} / \mathrm{l})$ in the absence or presence of the $\mathrm{H}_{2} \mathrm{~S}$ donor sodium hydrosulfide (NaHS; 50, 100 and $200 \mu \mathrm{mol} / \mathrm{l}$ ) for $12 \mathrm{~h}$, and cell viability was then determined by the Cell Counting Kit-8 (CCK-8) assay. Exposure of PC12 cells to $\mathrm{NaN}_{3}$ induced a decrease in cell viability. There was no effect on cell viability with $\mathrm{NaHS}$ pretreatment at a concentration of $50 \mathrm{mmol} / \mathrm{l}$. With NaHS pretreatment at a concentration of 100 and $200 \mu \mathrm{mol} / 1$, cell viability following injury increased in a concentration-dependent manner. Values are expressed as mean \pm standard error of the mean $(n=6)$. ${ }^{*} \mathrm{P}<0.05$ vs. control group; ${ }^{~} \mathrm{P}<0.05$ vs. $\mathrm{NaN}_{3}$ alone group.

$\mathrm{H}_{2} \mathrm{~S}$ protects $\mathrm{PCl} 2$ cells against $\mathrm{NaN}_{3}$-induced cytotoxicity. To investigate the effect of $\mathrm{H}_{2} \mathrm{~S}$ on $\mathrm{NaN}_{3}$-induced cytotoxicity, cell viability was analyzed by determining the percentage of CCK-8 reduction. As shown in Fig. 2, treatment with $\mathrm{NaN}_{3}$ at concentrations of $30 \mathrm{mmol} / \mathrm{l}$ for $12 \mathrm{~h}$ attenuated cell viability. The cytotoxic effects of $\mathrm{NaN}_{3}$ on $\mathrm{PC} 12$ cells were significantly prevented by pretreatment with NaHS at $100-200 \mu \mathrm{mol} / 1$ for $30 \mathrm{~min}$. At $200 \mu \mathrm{mol} / \mathrm{l}$, NaHS alone did not measurably affect the viability of $\mathrm{PC} 12$ cells.

$\mathrm{H}_{2} \mathrm{~S}$ exerts a protective effect against $\mathrm{NaN}_{3}$-induced dissipation of the mitochondrial membrane potential. To confirm that $\mathrm{NaN}_{3}$ induced a mitochondrial membrane potential reduction in $\mathrm{PC} 12$ cells, laser microscopy was used to visualize the fluorescence dye-stained mitochondria. When PC12 cells were exposed to $\mathrm{NaN}_{3}$, the mitochondrial membrane rapidly depolarized, as shown by the increase in green fluorescence (Fig. 3C). Pretreatment with NaHS reduced the changes in mitochondrial membrane potential, as indicated by repression of green fluorescence and restoration of red fluorescence (Fig. 3D). The quantitative analysis of the red/green ratios also demonstrated the protective role of $\mathrm{H}_{2} \mathrm{~S}$ in $\mathrm{NaN}_{3}$-induced a mitochondrial membrane potential reduction (Fig. 3E).

$\mathrm{H}_{2} \mathrm{~S}$ reduces $\mathrm{NaN}_{3}$-induced intracellular $\mathrm{ROS}$ accumulation in PC12 cells. The mitochondrion is considered to be the main site of ROS production, and an increased ROS level within the cell reflects mitochondrial dysfunction. Therefore, the effect of $\mathrm{H}_{2} \mathrm{~S}$ on ROS levels was investigated. $N$-acetyl-L-cysteine (NAC) is commonly used to identify and test ROS inducers and to inhibit ROS as a positive control. Intracellular ROS accumulation may be measured by the use of DCF-DA, which freely crosses the cell membrane. Once inside the cells, the compound is hydrolyzed by cellular esterase to DCF, which interacts with peroxides forming fluorescent 2',7'-dichlorofluorescin. PC12 cells treated with
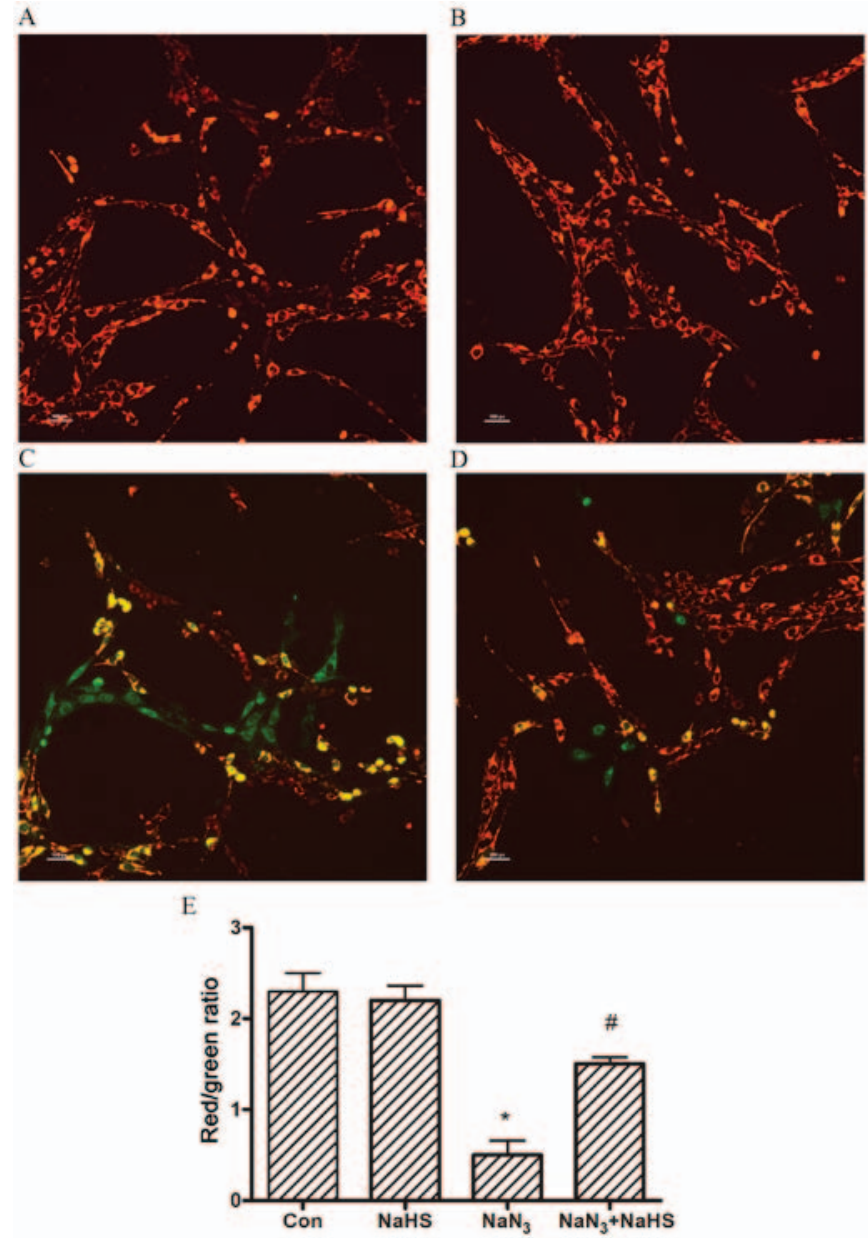

Figure 3. Effect of hydrogen sulfide $\left(\mathrm{H}_{2} \mathrm{~S}\right)$ on the mitochondrial membrane potential. Laser microscope images of JC-1 fluorescence (as an indicator of mitochondrial membrane potential) in PC12 cells after a 12-h exposure to $\mathrm{NaN}_{3}$ alone or in combination with $200 \mu \mathrm{mol} / 1$ sodium hydrosulfide (NaHS). (A) Control, (B) $200 \mu \mathrm{mol} / 1 \mathrm{NaHS}$, (C) $30 \mathrm{mmol} / 1 \mathrm{NaN}_{3}$, (D) $30 \mathrm{mmol} / 1 \mathrm{NaN} 3+200 \mu \mathrm{mol} / 1 \mathrm{NaHS}$, and (E) the bar chart demonstrates the quantitative analysis of the red/green ratio. The data are expressed as means \pm standard error of the mean $(n=6)$. ${ }^{*} \mathrm{P}<0.05$, significantly different from the control group; ${ }^{\#} \mathrm{P}<0.05$, significantly different from the $\mathrm{NaN}_{3}$ group. Scale bars, $30 \mu \mathrm{m}$.

$\mathrm{NaN}_{3}$ displayed intense fluorescence after staining with DCF dye (Fig. 4C). Intracellular ROS accumulation resulting from $\mathrm{NaN}_{3}$ treatment was significantly reduced when $\mathrm{H}_{2} \mathrm{~S}$ (Fig. 4D) or NAC (Fig. 4E) was present in the medium.

$\mathrm{H}_{2} \mathrm{~S}$ attenuates $\mathrm{NaN}_{3}$-induced lipid peroxidation increase in PC12 cells. When PC12 cells were exposed to $\mathrm{NaN}_{3}$ ( $30 \mathrm{mmol} / \mathrm{l}$ ) for $12 \mathrm{~h}$, an increase in the lipid peroxidation level, as indicated by the excessive formation of MDA in PC12 cells, was observed to $150 \%$ of control values (Fig. 5). Pretreatment with $\mathrm{H}_{2} \mathrm{~S}$ at concentrations of $200 \mu \mathrm{mol} / 1$ significantly decreased lipid peroxidation (decrease in the formation of MDA) compared with the levels observed in the $\mathrm{NaN}_{3}$ group.

$\mathrm{H}_{2} \mathrm{~S}$ suppresses $\mathrm{NaN}_{3}$-induced apoptosis in PC12 cells. To certify the effects of $\mathrm{H}_{2} \mathrm{~S}$ on $\mathrm{NaN}_{3}$-induced apoptosis, the following studies were performed: caspase- 3 is a critical marker of apoptosis. To determine the effects of $\mathrm{NaN}_{3}$ on 

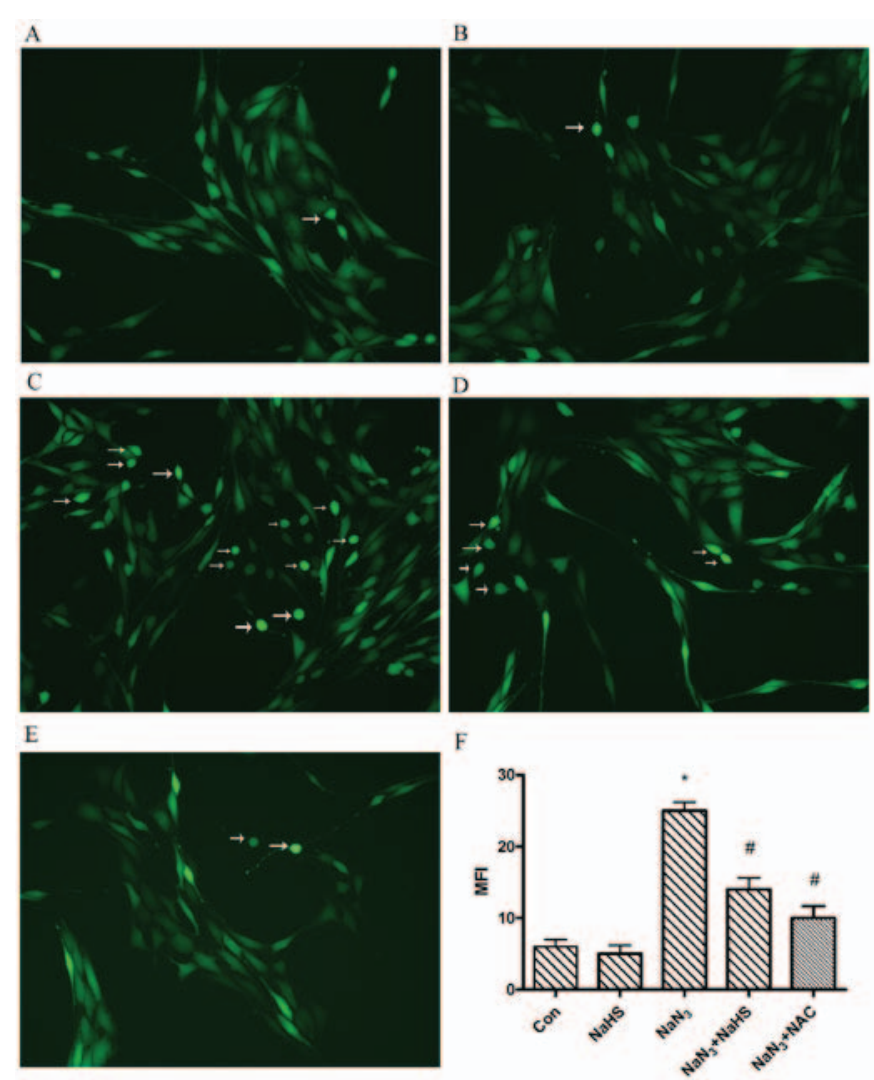

Figure 4. Protective effect of hydrogen sulfide $\left(\mathrm{H}_{2} \mathrm{~S}\right)$ on sodium azide $\left(\mathrm{NaN}_{3}\right)$-induced intracellular reactive oxygen species (ROS) accumulation. Intracellular peroxide levels were determined based on the dichlorofluorescein (DCF) fluorescence, as described in Materials and methods. Cells were plated and grown for $24 \mathrm{~h}$ and were then exposed to $\mathrm{NaN}_{3}$ in the presence or absence of NaHS. (A) Control,(B) $200 \mu \mathrm{mol} / 1 \mathrm{NaHS}$, (C) $30 \mathrm{mmol} / 1 \mathrm{NaN}_{3}$, (D) $30 \mathrm{mmol} / 1 \mathrm{NaN}_{3}+200 \mu \mathrm{mol} / 1 \mathrm{NaHS}$, (E) $30 \mathrm{mmol} / 1$ $\mathrm{NaN}_{3}+N$-acetyl-L-cysteine (NAC), and (F) the bar chart demonstrates the quantitative analysis of median fluorescence intensity (MFI). NAC is commonly used to identify and test ROS inducers, and to inhibit ROS. The data are expressed as means \pm standard error of the mean $(n=6) .{ }^{*} \mathrm{P}<0.05$, significantly different from the control group; ${ }^{\#} \mathrm{P}<0.05$, significantly different from the $\mathrm{NaN}_{3}$ group. Arrows indicate DCF-positive cells. Scale bars, $50 \mu \mathrm{m}$.

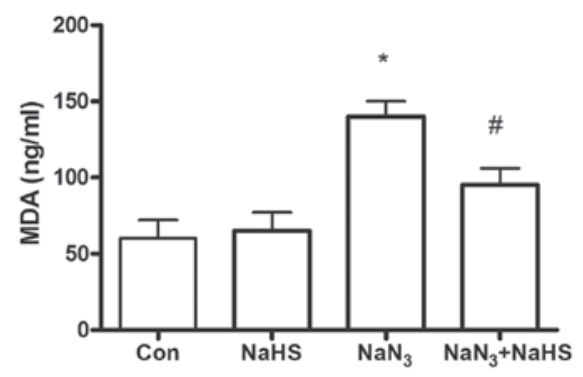

Figure 5. Effect of hydrogen sulfide $\left(\mathrm{H}_{2} \mathrm{~S}\right)$ on malondialdehyde (MDA) formation induced by sodium azide $\left(\mathrm{NaN}_{3}\right)$ in $\mathrm{PC} 12$ cells. MDA is a by-product of a free radical attack on lipids. PC12 cells were treated with $\mathrm{NaN}_{3}(30 \mathrm{mmol} / \mathrm{l})$ in the absence or presence of sodium hydrosulfide (NaHS; $200 \mu \mathrm{mol} / \mathrm{l}$ ) for $12 \mathrm{~h}$, and MDA was then determined by the thiobarbituric acid assay. Values are expressed as means \pm standard error of the mean $(n=6)$. ${ }^{*} \mathrm{P}<0.05$ vs. control group; ${ }^{\prime} \mathrm{P}<0.05$ vs. $\mathrm{NaN}_{3}$ alone group.

cell apoptosis and the response of $\mathrm{H}_{2} \mathrm{~S}$ to the effects of $\mathrm{NaN}_{3}$, the levels of caspase- 3 and Bcl-2 expression were measured by western blot analysis. As illustrated in Fig. 6, 12-h treatment with $\mathrm{NaN}_{3}(30 \mathrm{mmol} / \mathrm{l})$ significantly increased the
A

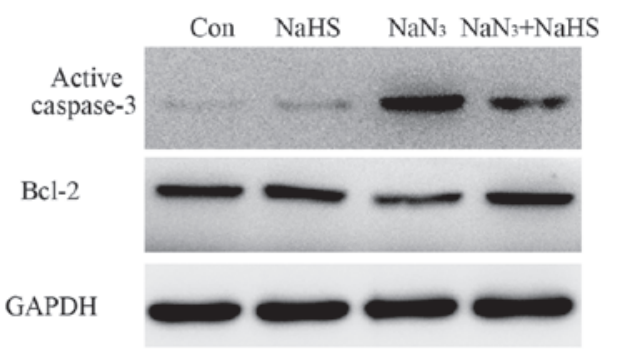

B

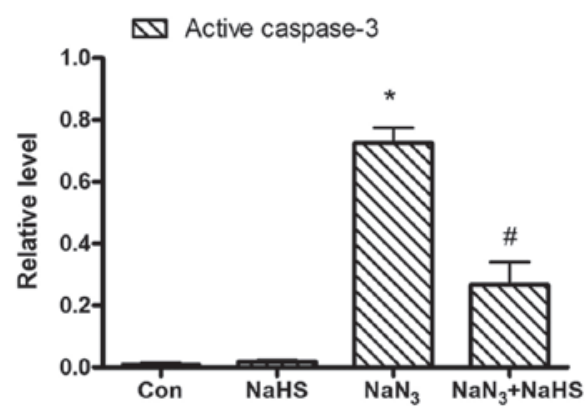

C

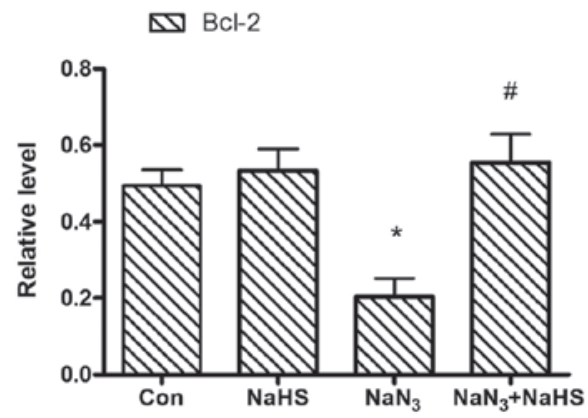

Figure 6. Effect of hydrogen sulfide $\left(\mathrm{H}_{2} \mathrm{~S}\right)$ on sodium azide $\left(\mathrm{NaN}_{3}\right)$-induced apoptosis-associated protein expression in PC12 cells. (A) Sample immunological probe for caspase-3, Bcl-2 and GAPDH. The bar chart demonstrates the ratio of caspase-3 or Bcl-2 relative to $\beta$-actin for different concentrations of $\mathrm{NaN}_{3}$. (B) A 12-h treatment with $\mathrm{NaN}_{3}(30 \mathrm{mmol} / \mathrm{l})$ significantly increased the amount of caspase- 3 expression, but (C) decreased the Bcl-2 expression. However, co-treatment with $200 \mu \mathrm{mol} / 1$ sodium hydrosulfide (NaHS) for $12 \mathrm{~h}$ significantly abolished the $\mathrm{NaN}_{3}$-induced increase in caspase- 3 expression and decrease in Bcl-2 expression. Con, control group. Semi-quantitative analysis (relative optical density) of the intensity of staining of caspase-3 or $\mathrm{Bcl}-2$ to $\beta$-actin for different concentrations of $\mathrm{NaN}_{3}$. The data are expressed as means \pm standard error of the mean $(n=3)$. ${ }^{*} \mathrm{P}<0.05$, significantly different from the control group; ${ }^{~} \mathrm{P}<0.05$ vs. $\mathrm{NaN}_{3}$ alone group.

amount of caspase-3 expression (Fig. 6B), but decreased Bcl-2 expression (Fig. 6C). However, co-treatment with $200 \mu \mathrm{mol} / 1 \mathrm{NaHS}$ for $12 \mathrm{~h}$ significantly abolished the $\mathrm{NaN}_{3}$-induced decrease in Bcl-2 expression and increase in caspase- 3 expression. These results indicate that $\mathrm{H}_{2} \mathrm{~S}$ is able to block the $\mathrm{NaN}_{3}$-elicited downregulation of Bcl-2 expression and upregulation of caspase-3 expression. In addition, we observed the effect of NaHS on autophagic cell death in PC12 cells treated with $\mathrm{NaN}_{3}$ by caspase- 3 staining. As shown in Fig. 7, at $12 \mathrm{~h}$ after treatment with $\mathrm{NaN}_{3}(30 \mathrm{mmol} / \mathrm{l})$, the number of caspase-3-positive cells observably increased. Co-treatment with NaHS (200 $\mu \mathrm{mol} / \mathrm{l})$ significantly ameliorated the $\mathrm{NaN}_{3}$-induced increase of caspase-3-positive cells. The control and NaHS-treated groups displayed few caspase-3-positive cells. 

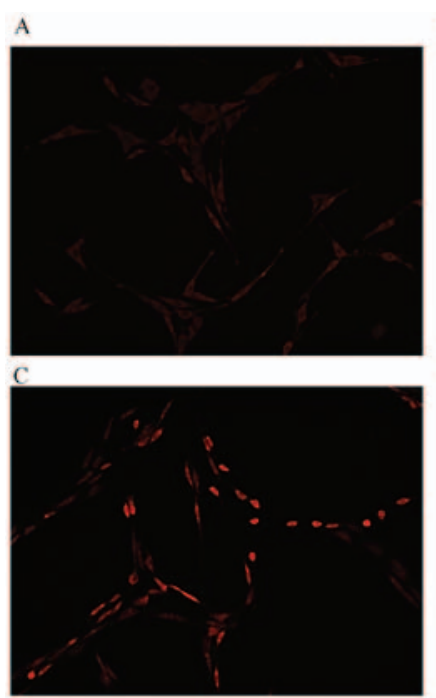

B
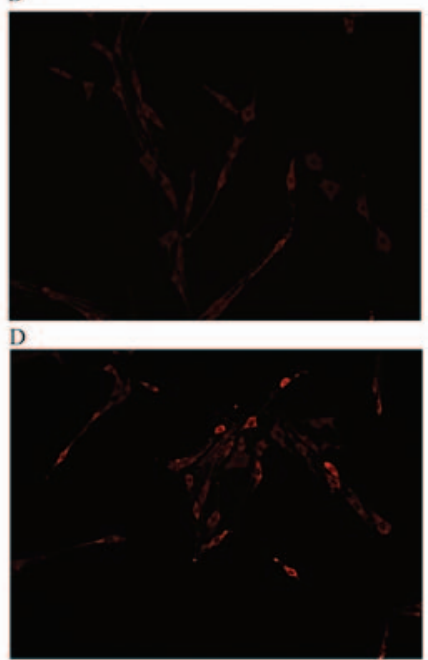

$\mathrm{E}$

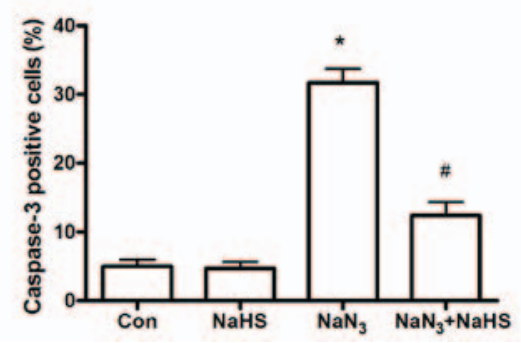

Figure 7. Effect of hydrogen sulfide $\left(\mathrm{H}_{2} \mathrm{~S}\right)$ on sodium azide $\left(\mathrm{NaN}_{3}\right)$-induced apoptosis in PC12 cells. Apoptosis was visualized as staining for caspase-3 in PC12 cells. (A) Control group, (B) sodium hydrosulfide (NaHS) group (C) $\mathrm{NaN}_{3}$ group, (D) $\mathrm{NaN}_{3}+\mathrm{NaHS}$ group and (E) the bar chart demonstrates the quantitative analysis of caspase-3-positive cells among the groups. The data are expressed as means \pm standard error of the mean $(n=3)$. ${ }^{*} \mathrm{P}<0.05$, significantly different from the control group; ${ }^{\prime} \mathrm{P}<0.05$ vs. injury group. Scale bars, $50 \mu \mathrm{m}$.

\section{Discussion}

Endogenous $\mathrm{H}_{2} \mathrm{~S}$ may have multiple physiological functions in the brain. Our previous study demonstrated that $\mathrm{H}_{2} \mathrm{~S}$ improved spatial memory impairment and alleviated cerebral edema in traumatic brain injury (TBI) mice $(15,16)$. A number of epidemiological studies provided compelling evidence that sustaining a TBI is associated with increased risk for degenerative conditions that may result in dementia, including $\mathrm{AD}$; however, several of the underlying mechanisms have yet to be fully elucidated. A complex disease such as AD involves multiple interwoven pathways leading to neuronal damage, whereas increasing evidence suggests that oxidative stress is one of the initiating events $(17,18)$. The aim of the present study was to examine the cell damage occurring in cultured PC12 cells when exposed to $\mathrm{NaN}_{3}$. Due to its ability to induce oxidative stress through inhibition of the electron transfer between COX and oxygen, this model represents an interesting tool in neurotoxicity studies. However, to the best of our knowledge, no study to date has investigated whether $\mathrm{H}_{2} \mathrm{~S}$ can prevent cytotoxicity induced by $\mathrm{NaN}_{3}$ in $\mathrm{PC} 12$ cells, and whether oxidative stress plays an important role in $\mathrm{NaN}_{3}$-induced apoptosis. In the present study, the possible molecular mechanisms underlying the neuroprotective effects of $\mathrm{H}_{2} \mathrm{~S}$ against $\mathrm{NaN}_{3}$-induced neuron cell injury were investigated. Furthermore, we investigated the connection between the generation of ROS and the activity of caspase-3 in $\mathrm{NaN}_{3}$-induced apoptosis in PC12 cells and demonstrated a concentration- and time-dependent reduction of cell viability induced by $\mathrm{NaN}_{3}$. Our findings demonstrated that $\mathrm{NaHS}$, a $\mathrm{H}_{2} \mathrm{~S}$ donor, attenuated $\mathrm{NaN}_{3}$-mediated apoptosis, and the anti-apoptotic action of $\mathrm{H}_{2} \mathrm{~S}$ was partly dependent on suppressing the production of ROS and inhibition of caspase-3 activity, and was associated with increasing the expression of the anti-apoptotic protein $\mathrm{Bcl}-2$.

$\mathrm{AD}$ is a multifactorial neurodegenerative disorder. Among the numerous contributing factors, cellular stress and, in particular, oxidative stress, have attracted considerable attention, as several studies reported its involvement in AD pathogenesis $(19,20)$. The evidence of oxidative damage in the postmortem AD brain is quite compelling, with significant accumulation of markers of oxidative damage of lipids, proteins and DNA, increased accumulation of transition metals, such as $\mathrm{Fe}, \mathrm{Cu}$ and $\mathrm{Zn}$, as well as impaired antioxidant defense (21). The recent redox proteomics analysis of the postmortem AD brain has demonstrated oxidative damage to key enzymes involved in energy metabolism, neurotransmitter-related proteins, mitochondrial proteins and proteasomal components (22). Multiple lines of evidence indicate that oxidative stress is an early event in $\mathrm{AD}$, occurring prior to cytopathological changes, and may therefore play a key pathogenic role in the disease $(20,23)$. Oxidative stress is the production of ROS in amounts exceeding the ability of the body's antioxidant systems to counteract their effects (24). These free radical species, which contain one or more unpaired electrons, act as electron donors, causing oxidation that potentially leads to damage of body macromolecular polymers, such as lipids, proteins and nucleic acids (25). The most important of all cell targets of ROS are nervous system cells, particularly neurons, which are highly susceptible to the harmful effects of ROS (26).

$\mathrm{NaN}_{3}$, as a COX inhibitor, has been extensively considered as a useful tool to study different pathological conditions. Mitochondrial energy metabolism is suggested to be a determining element for interpreting impaired neuron function, reduced molecular turnover, and enhanced cell death $(27,28)$. Inhibition of mitochondrial COX has been found to induce cell death in a variety of cells. Sato et al reported that SCC131 cells died 48-72 $\mathrm{h}$ after $\mathrm{NaN}_{3}$ treatment at concentrations more than $5 \mathrm{mM}$ (29). Lutton et al reported that $\mathrm{NaN}_{3}$ treatment at a concentration of $1 \mathrm{mM}$ induced necrosis in rat osteoclasts (30). In those studies, the longest treatment time required to induce cell death was more than $24 \mathrm{~h}$. The reason for this finding may be differences between the types of cells, specifically differential sensitivity of the excretory function or the detoxification function, and the quantity of the mitochondria of the target cells. PC12 cells, which are generally considered to display neuronal-like characteristics, appear to be more sensitive to $\mathrm{NaN}_{3}$. To induce oxidative stress in PC12 cells, $\mathrm{NaN}_{3}$ concentrations ranged from 1 to $10 \mathrm{mM}$ in several experiments $(31,32)$. Wang et al reported that the viability of PC12 cells treated with $64 \mathrm{mM} \mathrm{NaN}_{3}$ for $4 \mathrm{~h}$ decreased by $47.8 \%$ (33). Zhang et al reported that cultured PC12 cells was incubated with $\mathrm{NaN}_{3}$ $20 \mathrm{mM}$ for 3-24 h to induce apoptosis (34). Increased autophagy was also observed in multiple and distinct experimental injury models $(35,36)$. We tested the $5-\mathrm{mM}$ concentration of $\mathrm{NaN}_{3}$ at 
$36 \mathrm{~h}$. Although the result of the cell viability assay revealed that $\mathrm{NaN}_{3}$ induced cell death, autophagic cell death was not observed under these conditions. However, it is not known whether the role of autophagy is protective or detrimental for neural cell injury. It is possible that the role of autophagy after cell injury is dependent upon the cell's capacity to respond to the cumulative burden of damaged or dysfunctional macromolecules and organelles. If the increase in autophagic capacity is insufficient, augmenting autophagy would likely be beneficial. When there is excessive increase in autophagic capacity, inhibiting autophagy may be beneficial. Thus, the role of autophagy may be dictated by whether it is able to meet intracellular demands. The cell viability data were important in order to evaluate whether cells were still physiologically responsive, or if they were likely to be entering the cell death process. Therefore, the overall toxic effects of $\mathrm{NaN}_{3}$ was evaluated by monitoring cell viability in PC12 cells. In order to induce cell death in PC12 cells, high concentrations of $\mathrm{NaN}_{3}(30 \mathrm{mM})$ were applied in our experiments. Under these more severe stress conditions, when PC12 cell viability is already severely hampered, an accumulation of autophagic cell death was observed (37). A future study is planned to focus mainly on autophagic cell death in PC12 cells induced by $\mathrm{NaN}_{3}$.

Mitochondrial dysfunction induced by $\mathrm{NaN}_{3}$ provides a common platform for investigating the mechanisms of neuronal injury, which may prove useful for screening potential protective agents against neuronal death (38). Hyperoside has the neuroprotective capacity to attenuate $\mathrm{NaN}_{3}$-induced apoptosis in PC12 cells (34). Wang et al reported that aloe vera extract exerted a protective effect against mitochondrial functional impairment induced by $\mathrm{NaN}_{3}$ in $\mathrm{PC} 12$ cells (33). $\mathrm{H}_{2} \mathrm{~S}$ has increasingly been recognized as a gasotransmitter of comparable importance to nitric oxide and carbon monoxide in mammalian systems. Evidence suggests that these gasotransmitters are involved in the origin of life and play key roles in the endosymbiotic events that contribute to the biogenesis and development of mitochondria. In addition to its function as a signaling molecule, $\mathrm{H}_{2} \mathrm{~S}$ also acts as a cytoprotectant in neurons and cardiac muscle (11). The neuroprotective properties of $\mathrm{H}_{2} \mathrm{~S}$ have long been observed, leading to extensive research that has been widely reported and continues to attract interest (39). In a rat model, it was demonstrated that $\mathrm{H}_{2} \mathrm{~S}$ exerts a protective effect and diminishes oxidative stress and homocysteine-induced toxicity by its antioxidant properties in the adrenal medulla and smooth muscle cells of the vesicles (40). This raises the possibility of $\mathrm{H}_{2} \mathrm{~S}$ being a possible therapeutic strategy in the treatment of neurodegenerative disorders. To investigate whether ROS are involved in $\mathrm{NaN}_{3}$-induced injury, PC12 cells were pretreated with NAC (a ROS scavenger) prior to exposure to $\mathrm{NaN}_{3}$. The cell viability data were important in order to evaluate if cells remained physiologically responsive, or if they were likely to be entering cell death. We observed that $\mathrm{NaN}_{3}$ induced not only ROS production, but also initiated injury of $\mathrm{PC} 12$ cells, including a decrease in cell viability, loss of MMP and caspase-3 activation, as well as an increase in the number of apoptotic cells. These effects were significantly prevented by $\mathrm{NAC}$ pretreatment, indicating that $\mathrm{NaN}_{3}$-induced neuronal injury is due to its induction of ROS. Exogenously applied free $\mathrm{H}_{2} \mathrm{~S}$ is immediately absorbed in a sulfur store as bound sulfane sulfur (41). $\mathrm{H}_{2} \mathrm{~S}$ may be transiently stored and then released when the cells are stimulated. $\mathrm{H}_{2} \mathrm{~S}$ is absorbed in brain homogenates more slowly compared with liver and heart homogenates, and the release from brain homogenates is also slower compared with that from liver and heart homogenates $(41,42)$. Once $\mathrm{H}_{2} \mathrm{~S}$ is released from bound sulfane sulfur or from $\mathrm{H}_{2} \mathrm{~S}$-producing enzymes, free $\mathrm{H}_{2} \mathrm{~S}$ may remain longer in the brain compared with the liver and the heart. Therefore, considering the slow absorption of $\mathrm{H}_{2} \mathrm{~S}$ in the brain, pretreatment with NaHS was selected. Interestingly, it was observed that NaHS (a donor of $\mathrm{H}_{2} \mathrm{~S}$ ) shared similar neuroprotective properties with NAC with a comparable potency in this experimental model. This may support the ability of $\mathrm{H}_{2} \mathrm{~S}$ in: i) inhibiting $\mathrm{NaN}_{3}$-mediated protein cytotoxicity; ii) inhibiting $\mathrm{NaN}_{3}$-mediated oxidative damage; and iii) inhibiting generation of ROS induced by $\mathrm{NaN}_{3}$.

$\mathrm{H}_{2} \mathrm{~S}$ is synthesized in a number of different cell types and can easily diffuse without involvement of any transporters. $\mathrm{H}_{2} \mathrm{~S}$ is involved in a number of organ-specific functions, such as thermoregulation, modulating myocardial activity and bronchodilation (43). $\mathrm{H}_{2} \mathrm{~S}$ also exerts organ-protective effects in ischaemia, acting as a vasodilator and negative inotrope to reduce blood pressure (44). A number of studies have investigated the possible benefit of $\mathrm{H}_{2} \mathrm{~S}$ in hypertension, and found that $\mathrm{H}_{2} \mathrm{~S}$ donor administration significantly reduced blood pressure and oxidative stress in hypertensive mice $(45,46) . \mathrm{H}_{2} \mathrm{~S}$ has also been found to play a role in the pathology and treatment of chronic obstructive pulmonary disease. Exogenously supplied $\mathrm{H}_{2} \mathrm{~S}$ may counteract the oxidative stress-mediated lung damage that occurs in allergic mice (47). Low $\mathrm{H}_{2} \mathrm{~S}$ levels have been observed in a number of different diseases, while there is evidence that $\mathrm{H}_{2} \mathrm{~S}$ may be beneficial in a number of chronic organ degenerative conditions. Chronic kidney disease is associated with a significant reduction in plasma $\mathrm{H}_{2} \mathrm{~S}$ concentration, and $\mathrm{H}_{2} \mathrm{~S}$ may ameliorate adenine-induced chronic renal failure in rats by inhibiting apoptosis through ROS signaling pathways (48). Diabetes is a chronic metabolic disease affecting the metabolism of carbohydrates and other nutrients. $\mathrm{H}_{2} \mathrm{~S}$ protects against the development of hyperglycemia-induced endothelial dysfunction by attenuating the hyperglycemia-induced enhancement of ROS formation (49). As regards degenerative diseases of the CNS, $\mathrm{H}_{2} \mathrm{~S}$ treatment can specifically inhibit 6-OHDA-evoked NADPH oxidase activation and oxygen consumption in Parkinson's disease (50). Moreover, $\mathrm{H}_{2} \mathrm{~S}$ protects neurons against oxidative stress, which is responsible for neuronal damage and degeneration in $\mathrm{AD}$ (51). In conclusion, $\mathrm{H}_{2} \mathrm{~S}$ donors have consistently been shown to be beneficial in acute organ injury and in chronic organ pathology through ROS signaling pathways. More specifically, data available thus far strongly suggest that $\mathrm{H}_{2} \mathrm{~S}$ may be a potent preventive and therapeutic agent used for the prevention and improvement of the symptoms of oxidative stress-associated diseases, which is worthy of further investigation in future studies.

Although $\mathrm{H}_{2} \mathrm{~S}$ exhibited promising efficacy in $\mathrm{NaN}_{3}$-mediated cell injury, research is still underway to identify selective oxidative stress regulators as potential treatment drugs. In summary, the evidence presented herein indicates an actively protective role for $\mathrm{H}_{2} \mathrm{~S}$ against oxidative stress and apoptosis induced by $\mathrm{NaN}_{3}$. Our data may provide a novel pathway to elucidate the underlying molecular and cellular mechanisms 
in the CNS following inhibition of COX, and a novel strategy for the treatment of CNS diseases. Future studies attempting to characterize the functional consequences of $\mathrm{H}_{2} \mathrm{~S}$ under conditions of oxidative stress and the identification of substrates and downstream signaling targets are now possible. Other $\mathrm{H}_{2} \mathrm{~S}$ donors, such as drug-like $\mathrm{H}_{2} \mathrm{~S}$ donor ATB-346 or orally active $\mathrm{H}_{2} \mathrm{~S}$ donor SG-1002, may be used to evaluate the protective effect of $\mathrm{H}_{2} \mathrm{~S}$ in injury models in the future. Testing these drug-like $\mathrm{H}_{2} \mathrm{~S}$ donors will not only consolidate the protective effect of $\mathrm{H}_{2} \mathrm{~S}$, but also shed light on the clinical application of $\mathrm{H}_{2} \mathrm{~S}$ as a therapeutic agent.

\section{Acknowledgements}

The present study was supported by the National Natural Science Foundation of China (grant nos. 81601306, 81301039 and 81530062); the China Postdoctoral Science Foundation Funded Project (grant no. 2015M570476); the Priority Academic Program Development of Jiangsu Higher Education Institutions (PAPD); the Jiangsu Talent Youth Medical Program (grant no. QNRC2016245); the Key Laboratory of Evidence Science (China University of Political Science and Law), Ministry of Education (grant no. 2016KFKT05); the Shanghai Key Laboratory of Forensic Medicine (grant no. KF1502); and the Suzhou Science and Technology Development Project (grant no. SYSD2015119).

\section{References}

1. Takahashi RH, Nagao T and Gouras GK: Plaque formation and the intraneuronal accumulation of $\beta$-amyloid in Alzheimer's disease. Pathol Int 67: 185-193, 2017.

2. Martinez-Vicente M: Neuronal mitophagy in neurodegenerative diseases. Front Mol Neurosci 10: 64, 2017.

3. Menzies FM, Fleming A, Caricasole A, Bento CF, Andrews SP, Ashkenazi A, Füllgrabe J, Jackson A, Jimenez Sanchez M, Karabiyik C, et al: Autophagy and neurodegeneration: pathogenic mechanisms and therapeutic opportunities. Neuron 93: 1015-1034, 2017.

4. Cai Q and Tammineni P: Alterations in mitochondrial quality control in Alzheimer's disease. Front Cell Neurosci 10: 24, 2016.

5. Cai Q and Tammineni P: Mitochondrial aspects of synaptic dysfunction in Alzheimer's disease. J Alzheimers Dis 57: 1087-1103, 2017

6. Cadonic C, Sabbir MG and Albensi BC: Mechanisms of mitochondrial dysfunction in Alzheimer's disease. Mol Neurobiol 53 : 6078-6090, 2016.

7. Bennett MC, Mlady GW, Kwon YH and Rose GM: Chronic in vivo sodium azide infusion induces selective and stable inhibition of cytochrome $c$ oxidase. J Neurochem 66: 2606-2611, 1996.

8. Weinstock M and Shoham S: Rat models of dementia based on reductions in regional glucose metabolism, cerebral blood flow and cytochrome oxidase activity. J Neural Transm (Vienna) 111: 347-366, 2004

9. Huang $\mathrm{CW}$ and Moore PK: $\mathrm{H}_{2} \mathrm{~S}$ synthesizing enzymes: biochemistry and molecular aspects. Handb Exp Pharmacol 230 $3-25,2015$.

10. Kimura H: Hydrogen sulfide and polysulfides as biological mediators. Molecules 19: 16146-16157, 2014.

11. Kimura H: Hydrogen sulfide: its production, release and functions. Amino Acids 41: 113-121, 2011.

12. Liu Y, Deng Y, Liu H, Yin C, Li X and Gong Q: Hydrogen sulfide ameliorates learning memory impairment in APP/PS1 transgenic mice: a novel mechanism mediated by the activation of $\mathrm{Nrf2}$. Pharmacol Biochem Behav 150-151: 207-216, 2016.

13. Dwyer BE, Raina AK, Perry G and Smith MA: Homocysteine and Alzheimer's disease: a modifiable risk? Free Radic Biol Med 36: 1471-1475, 2004.

14. Wei HJ, Li $X$ and Tang XQ: Therapeutic benefits of $\mathrm{H}_{2} \mathrm{~S}$ in Alzheimer's disease. J Clin Neurosci 21: 1665-1669, 2014.
15. Zhang M, Shan H, Chang P, Wang T, Dong W, Chen X and Tao L: Hydrogen sulfide offers neuroprotection on traumatic brain injury in parallel with reduced apoptosis and autophagy in mice. PLoS One 9: e87241, 2014.

16. Zhang M, Shan H, Wang T, Liu W, Wang Y, Wang L, Zhang L, Chang P, Dong W, Chen X, et al: Dynamic change of hydrogen sulfide after traumatic brain injury and its effect in mice. Neurochem Res 38: 714-725, 2013.

17. Tayler H, Fraser T, Miners JS, Kehoe PG and Love S: Oxidative balance in Alzheimer's disease: relationship to APOE, Braak tangle stage, and the concentrations of soluble and insoluble amyloid- $\beta$. J Alzheimers Dis 22: 1363-1373, 2010.

18. Chauhan V and Chauhan A: Oxidative stress in Alzheimer's disease. Pathophysiology 13: 195-208, 2006.

19. Henriques AG, Domingues SC, Fardilha M, da Cruz e Silva EF and da Cruz e Silva OA: Sodium azide and 2-deoxyD-glucose-induced cellular stress affects phosphorylationdependent AbetaPP processing. J Alzheimers Dis 7: 201-212, 2005.

20. Zhu X, Raina AK, Lee HG, Casadesus G, Smith MA and Perry G: Oxidative stress signalling in Alzheimer's disease. Brain Res 1000: 32-39, 2004.

21. Butterfield DA, Swomley AM and Sultana R: Amyloid $\beta$-peptide (1-42)-induced oxidative stress in Alzheimer disease: importance in disease pathogenesis and progression. Antioxid Redox Signal 19: 823-835, 2013.

22. Butterfield DA, Di Domenico F, Swomley AM, Head E and Perluigi M: Redox proteomics analysis to decipher the neurobiology of Alzheimer-like neurodegeneration: overlaps in Down's syndrome and Alzheimer's disease brain. Biochem J 463: 177-189, 2014.

23. Petersen RB, Nunomura A, Lee HG, Casadesus G, Perry G, Smith MA and Zhu X: Signal transduction cascades associated with oxidative stress in Alzheimer's disease. J Alzheimers Dis 11: 143-152, 2007.

24. Dringen R: Metabolism and functions of glutathione in brain. Prog Neurobiol 62: 649-671, 2000.

25. Gadalla MM and Snyder SH: Hydrogen sulfide as a gasotransmitter. J Neurochem 113: 14-26, 2010.

26. Dumont M and Beal MF: Neuroprotective strategies involving ROS in Alzheimer disease. Free Radic Biol Med 51: 1014-1026, 2011.

27. Ott M, Gogvadze V, Orrenius S and Zhivotovsky B: Mitochondria, oxidative stress and cell death. Apoptosis 12: 913-922, 2007.

28. Yin F, Boveris A and Cadenas E: Mitochondrial energy metabolism and redox signaling in brain aging and neurodegeneration. Antioxid Redox Signal 20: 353-371, 2014.

29. Sato E, Suzuki T, Hoshi N, Sugino T and Hasegawa H: Sodium azide induces necrotic cell death in rat squamous cell carcinoma SCC131. Med Mol Morphol 41: 211-220, 2008.

30. Lutton JD, Moonga BS and Dempster DW: Osteoclast demise in the rat: physiological versus degenerative cell death. Exp Physiol 81: 251-260, 1996.

31. Amador FC, Henriques AG, da Cruz E Silva OA and da Cruz E Silva EF: Monitoring protein phosphatase 1 isoform levels as a marker for cellular stress. Neurotoxicol Teratol 26: 387-395, 2004.

32. Satpute R, Bhattacharya R, S Kashyap R, J Purohit H, Y Deopujari J, M Taori G and F Daginawala H: Antioxidant potential of Fagonia arabica against the chemical ischemia-induced in PC12 cells. Iran J Pharm Res 11: 303-313, 2012.

33. Wang Y, Cao L and Du G: Protective effects of Aloe vera extract on mitochondria of neuronal cells and rat brain. Zhongguo Zhong Yao Za Zhi 35: 364-368, 2010 (In Chinese).

34. Zhang L, Cheng $X$ and Hu J: Neuroprotective effects of hyperoside on sodium azide-induced apoptosis in PC12 cells. Chin J Nat Med 9: 450-455, 2011.

35. Smith CM, Chen Y, Sullivan ML, Kochanek PM and Clark RS: Autophagy in acute brain injury: feast, famine, or folly? Neurobiol Dis 43: 52-59, 2011.

36. Liu L, Sun T, Xin F, Cui W, Guo J and Hu J: Nerve growth factor protects against alcohol-induced neurotoxicity in PC12 cells via PI3K/Akt/mTOR pathway. Alcohol Alcohol 52: 12-18, 2017.

37. Shan H, Chu Y, Chang P, Yang L, Wang Y, Zhu S, Zhang M and Tao L: Neuroprotective effects of hydrogen sulfide on sodium azide-induced autophagic cell death in PC12 cells. Mol Med Rep: Aug 25, 2017 (Epub ahead of print).

38. Selvatici R, Previati M, Marino S, Marani L, Falzarano S, Lanzoni I and Siniscalchi A: Sodium azide induced neuronal damage in vitro: evidence for non-apoptotic cell death. Neurochem Res 34: 909-916, 2009. 
39. Kimura H: Hydrogen sulfide: production, release, and functions. Nippon Yakurigaku Zasshi 139: 6-8, 2012 (In Japanese).

40. Zhang Y, Tang ZH, Ren Z, Qu SL, Liu MH, Liu LS and Jiang ZS: Hydrogen sulfide, the next potent preventive and therapeutic agent in aging and age-associated diseases. Mol Cell Biol 33: 1104-1113, 2013.

41. Ishigami M, Hiraki K, Umemura K, Ogasawara $\mathrm{Y}$, Ishii $\mathrm{K}$ and Kimura H: A source of hydrogen sulfide and a mechanism of its release in the brain. Antioxid Redox Signal 11: 205-214, 2009.

42. Kimura H: Hydrogen sulfide: from brain to gut. Antioxid Redox Signal 12: 1111-1123, 2010.

43. Yu XH, Cui LB, Wu K, Zheng XL, Cayabyab FS, Chen ZW and Tang CK: Hydrogen sulfide as a potent cardiovascular protective agent. Clin Chim Acta 437: 78-87, 2014.

44. Jin Z, Chan H, Ning J, Lu K and Ma D: The role of hydrogen sulfide in pathologies of the vital organs and its clinical application. J Physiol Pharmacol 66: 169-179, 2015.

45. Al-Magableh MR, Kemp-Harper BK and Hart JL: Hydrogen sulfide treatment reduces blood pressure and oxidative stress in angiotensin II-induced hypertensive mice. Hypertens Res 38: 13-20, 2015.

46. Meng G, Ma Y, Xie L, Ferro A and Ji Y: Emerging role of hydrogen sulfide in hypertension and related cardiovascular diseases. Br J Pharmacol 172: 5501-5511, 2015.
47. Benetti LR, Campos D, Gurgueira SA, Vercesi AE, Guedes CE, Santos KL, Wallace JL, Teixeira SA, Florenzano J, Costa SK, et al: Hydrogen sulfide inhibits oxidative stress in lungs from allergic mice in vivo. Eur J Pharmacol 698: 463-469, 2013.

48. Wu D, Luo N, Wang L, Zhao Z, Bu H, Xu G, Yan Y, Che X, Jiao Z, Zhao T, et al: Hydrogen sulfide ameliorates chronic renal failure in rats by inhibiting apoptosis and inflammation through

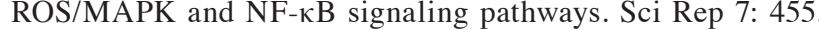
2017.

49. Suzuki K, Olah G, Modis K, Coletta C, Kulp G, Gerö D, Szoleczky P, Chang T, Zhou Z, Wu L, et al: Hydrogen sulfide replacement therapy protects the vascular endothelium in hyperglycemia by preserving mitochondrial function. Proc Natl Acad Sci USA 108: 13829-13834, 2011.

50. $\mathrm{Hu} \mathrm{LF}, \mathrm{Lu} \mathrm{M}$, Tiong CX, Dawe GS, Hu G and Bian JS: Neuroprotective effects of hydrogen sulfide on Parkinson's disease rat models. Aging Cell 9: 135-146, 2010.

51. Kimura Y and Kimura H: Hydrogen sulfide protects neurons from oxidative stress. FASEB J 18: 1165-1167, 2004. 